IZA DP No. 4531

Does Formality Improve Micro-Firm Performance?

Quasi-Experimental Evidence from the Brazilian SIMPLES Program

Pablo Fajnzylber

William F. Maloney

Gabriel V. Montes-Rojas

October 2009 


\title{
Does Formality Improve Micro-Firm Performance? \\ Quasi-Experimental Evidence from the Brazilian SIMPLES Program
}

Pablo Fajnzylber

World Bank

William F. Maloney

World Bank and IZA

\section{Gabriel V. Montes-Rojas}

City University London

\section{Discussion Paper No. 4531 \\ October 2009}

\author{
IZA \\ P.O. Box 7240 \\ 53072 Bonn \\ Germany \\ Phone: +49-228-3894-0 \\ Fax: +49-228-3894-180 \\ E-mail: iza@iza.org
}

\begin{abstract}
Any opinions expressed here are those of the author(s) and not those of IZA. Research published in this series may include views on policy, but the institute itself takes no institutional policy positions.

The Institute for the Study of Labor (IZA) in Bonn is a local and virtual international research center and a place of communication between science, politics and business. IZA is an independent nonprofit organization supported by Deutsche Post Foundation. The center is associated with the University of Bonn and offers a stimulating research environment through its international network, workshops and conferences, data service, project support, research visits and doctoral program. IZA engages in (i) original and internationally competitive research in all fields of labor economics, (ii) development of policy concepts, and (iii) dissemination of research results and concepts to the interested public.
\end{abstract}

IZA Discussion Papers often represent preliminary work and are circulated to encourage discussion. Citation of such a paper should account for its provisional character. A revised version may be available directly from the author. 
IZA Discussion Paper No. 4531

October 2009

\section{ABSTRACT \\ Does Formality Improve Micro-Firm Performance? Quasi-Experimental Evidence from the Brazilian SIMPLES Program*}

This paper employs regression discontinuity methods to identify the effect of formality on Brazilian micro-firm performance. The SIMPLES program introduced in November 1996 consolidated multiple taxes and social security contributions into a single payment and reduced taxes for eligible small firms. This provides a quasi-natural experiment that allows us to eliminate many of the endogeneity issues surrounding the impact of formality, measured across several dimensions, on firm performance. We find that SIMPLES had a significant effect on the proportion of firms that have a license to operate, are registered as a legal entity, pay taxes and make social security contributions. Moreover, newly created firms that opt for operating formally achieve higher levels of revenue and profits, employ more workers and are more capital intensive (only for those firms that have employees). The channel through which this occurs is not access to credit or contracts with larger firms. Rather, it appears that the lower cost of contracting labor leads to adopting production techniques that involve greater permanence and a larger paid labor force.

JEL Classification: J23, L25

Keywords: micro-firms, self-employment, informality

Corresponding author:

Gabriel V. Montes-Rojas

Department of Economics

City University London

10 Northampton Square

London EC1V OHB

United Kingdom

E-mail: Gabriel.Montes-Rojas.1@city.ac.uk

\footnotetext{
* We are grateful to Mark Rosenzweig, two anonymous referees and Laura Chioda for helpful comments and suggestions.
} 


\section{Introduction}

This paper exploits an extensive Brazilian micro-enterprise survey and the 1996 introduction of a business tax reduction and simplification scheme "SIMPLES" (Integrated System for the Payment of Taxes and Social Security Contributions of Micro and Small Enterprises) ${ }^{1}$ to examine three questions. First, do high tax rates and complex tax regulations really constitute a barrier to the formalization of micro firms? Second, does formalization improve firm performance measured along several dimensions, including revenues, employment and capital stock? Third, what are the channels through which this occurs?

Starting with De Soto’s (1989) “The Other Path” barriers to participating in governmental institutions, and in particular, the very high costs of complying with government regulations, have often been seen as largely responsible for the presence of large informal sectors in developing countries. Since De Soto found that a firm would need to spend 289 days complying with all necessary red tape in Peru, initiatives, such as the World Bank Doing Business project, have systematically collected data on registration costs for a large set of countries confirming that the burden on firms is, on paper, very onerous. In turn, the inability to become formal is thought to have deleterious

effects on performance. As examples, formality offers the firm access to risk pooling mechanisms that may attract more educated paid workers and engage them in a longer relationship with the firm, which in turn makes training and capital goods acquisition more profitable. Formality may be a requirement for access to formal credit markets or Government provided business development services or, as De Paula and Scheinkman (2007) have argued, for subcontracting relations with formal firms. ${ }^{2}$ Moreover, to the extent that formality increases the ability of micro-entrepreneurs to establish property rights over their investments and reduces the risk of being fined by Government

\footnotetext{
${ }^{1}$ SIMPLES stands for "Sistema Integrado de Pagamento de Impostos e Contribuçoes das Microempresas e Empresas de Pequeno Porte.”

2 Note, however, that formality may also reduce firms' flexibility to fire workers in the presence of negative shocks (see for instance Heckman and Pages, 2004). For Brazilian medium and large firms, Almeida and Carneiro (2005) found that stricter enforcement of labor regulation had a negative impact on firm performance. These findings are more in line with Gerxhani's (2004) and Loayza et al.'s (2005) view of informality as a tax-evading activity.
} 
inspectors, it creates incentives for operating out of fixed locations rather than in an ambulatory fashion.

But this said, establishing the existence of high costs of regulatory compliance does not, in itself, establish either that this is why firms remain informal, or that informality is a fundamental determinant of average small firm performance. De Soto's telling anecdotes - e.g. the sidewalk vendor who wishes to pay his taxes as a way of securing quasi-property rights to his pitch - do suggest that high costs of formalization may impede the formalization of micro firms and negatively affect their performance. However, the costs of regulatory compliance are only one of the factors that informal firms are likely to consider when undertaking the cost benefit analysis of entering the formal sector and within this calculus those costs may not be a binding constraint.

For instance, Levenson and Maloney (1998) treat formality broadly construed as participation in the institutions of civil society and argue that, if formality broadly construed operates as a normal input in the production function of firms, it is possible that the intrinsic cost structure of many informal enterprises may dictate that they never grow large enough to need those institutions. Family firms with one employee may not need risk pooling mechanisms, their client base may be neighbors, and their small steady state size may make credit institutions relatively unimportant. The view of the potential irrelevance of formality to many micro firms is supported by recent evidence on Mexico by McKenzie and Woodruff's (2006). Using a survey of informal micro firms they show that the vast majority of them give as the principal reason for not being registered, not that it is too expensive or time consuming to do so (respectively $2 \%$ and $8 \%$ of surveyed firms), nor that the costs of operating as registered businesses are too high ( $4 \%$ of firms), but that they are too small to make it worth their while (75\%). This suggests that, for most small firms, registration costs may be at best a marginal contributor to informality and that formality itself is not important from the point of view of micro firm growth.

These findings suggest that selection bias is likely to be a major issue. In the view above, more productive firms are the ones likely to expand and hence need formality. An 
important part of any correlation of formality with productivity is potentially driven by the firm's underlying characteristics not by formality per se. Working in the same direction, more successful businesses are more likely to be detected by government inspectors especially as they grow, which may lead them to formalize in order to avoid paying fines and/or bribes.

On the other hand, there are reasons to expect downward bias as well. First, Farrell (2004) argues that avoiding taxes and regulations makes small sized informal firms more able to compete with their larger formal counterparts. For a low productivity firm serving his neighbors, this may be less relevant that for a somewhat more productive firm with aspirations to larger market share who may be at the top of the size distribution of our data. Second, Almeida and Carneiro (2005) argue that in Brazil informality appears to allow firms greater flexibility in their employment and production decisions which, in turn, allows them to operate more efficiently. Thus, high productivity firms that expect to hire labor may choose to find ways to avoid becoming formal in order to maintain this flexibility. This may be especially relevant in the present case since an important element of the SIMPLES was reducing the costs of social security payments for small firms. While we cannot say a priori, which of these effects or others may dominate, we have good reasons to expect that simply regressing performance on a formality dummy will yield biased estimates.

Various approaches have been used to correct for this selection bias. Fajnzylber et al. (2009) for Mexico employ both matching and traditional control function methods to control for selection into formality using both observables and unobservables. Their results confirm that formality does rise with time in business and size, consistent with it being a normal input, and they find that registering with tax authorities does have an impact on firms' profits and survival likelihood. Their work says little about barriers to regularizing, per se, only that there are, in fact, net benefits.

Another arguably more powerful approach seeks to exploit the changes in the norms surrounding registration costs and tax rates for small firms in a quasi-experimental 
context. For Mexico, where the $\mathrm{SARE}^{3}$ program created one stop shops to facilitate registration procedures for eligible micro, small and medium firms, Kaplan et al. (2006) use ineligible firms as a control group in a difference in difference context, and show that SARE led to an increase of between 4 and $8 \%$ in the flow of newly registered firms. Although this effect is statistically significant, its magnitude is quantitatively small, implying only about two to five new firms registered and about 12 to 19 new formal jobs per municipality per month. Bruhn (2008), exploiting the same innovation but different data sources found a larger rise in formalization: an increase of about $5 \%$ in the stock of registered businesses in eligible industries. ${ }^{4}$ However, she shows that the effect of SARE comes exclusively from former salaried workers opening formal micro firms, instead of through the formalization of existing non-registered businesses.

For Brazil, Monteiro and Assunção (2006) exploit the same administrative simplification and tax reduction program used in the present paper applying a differencein-differences approach with ineligible firms as a control group. They find that SIMPLES increased formal licensing for only one sector -retail firms (by 13 percentage points), but that it had no impact on eligible firms from construction, manufacturing, transportation and other services. In sum, the three quasi-experimental studies find little evidence that registration costs are particularly important to formalization.

Our work revisits this data taking several approaches that potentially may yield more definitive results. First, we exploit the regression discontinuity (RD) introduced by SIMPLES on formality and bring the set of tools developed by that literature to bear. We also extend these to strengthen Monteiro and Assunção’s (2006) difference in-differences estimator. Second, we explore the impact of SIMPLES on a range of formality

\footnotetext{
3 SARE stands for "Sistema de Apertura Rápida de Empresas." It was implemented in selected municipalities and consolidated in single local offices all the federal, state and municipal procedures needed to register a firm, reducing the total duration of the process to at most 48 hours. Kaplan et al. use data both from municipalities where the SARE was actually implemented and, as additional control groups, from other "competing" municipalities which were chosen to participate in SARE but where the program has not yet being launched.

${ }^{4}$ The much smaller impact found by Kaplan et al. could be due to the fact that their data cover only firms registered with Mexico's Social Security Institute (IMSS) while Bruhn's employment data also cover the large majority of owner-only microenterprises for which registration with IMSS is not mandatory.
} 
dimensions beyond licensing. Third, we employ a local estimator at the time of the policy change to document the effects of formality on various measures of firm performance, including revenues, and profits. Finally, we explore a broad set of channels through which formality may give rise to improved firm performance.

The paper is structured as follows. Section II describes the main regulatory changes introduced by SIMPLES. Section III characterizes the data used in the econometric analysis and provides some basic descriptive statistics on Brazilian urban micro-firms - i.e. their average size, entrepreneurs' motivations for being in business and level of formality. Section IV presents visual evidence on the discontinuity introduced by SIMPLES in the formality rates of Brazilian micro-firms. Section V describes our estimation approach and econometric results. Conclusions follow in Section VI.

\section{The SIMPLES Program}

In November 1996, the Brazilian Government implemented a new simplified tax system for micro (up to R $\$ 120,000$ ) and small firms (up to R\$720,000), the SIMPLES. ${ }^{5}$ The new national system consolidated several federal taxes and social security contributions into one single monthly payment, varying from $3 \%$ to $5 \%$ of gross revenues for micro-enterprises, and from $5.4 \%$ to $7 \%$ of revenues for small firms. The initial executive decree $\left(\mathrm{n}^{\circ}\right.$ 1516) included a unique 5\% tax rate for all micro-enterprises, but this was modified a month later in Law $\mathrm{n}^{\circ}$ 9317, which introduced lower tax rates for smaller micro-firms. The taxes and contributions covered by SIMPLES are ${ }^{6}$ Imposto de Renda das Pessoas Jurídicas - IRPJ (corporate income tax); Imposto sobre Produtos Insutrializados - IPI (tax on industrialized products); Contribução para o PIS/PASEP (social security contribution to fund unemployment insurance and other social programs); Contribução Social sobre o Lucro Liquido - CSLL (social security contribution on net

\footnotetext{
${ }^{5}$ One US dollar was equivalent to R\$ 1.04 in December 1996 and R\$ 1.1 in October 1997, the time of the ECINF 1997. We leave the amounts denominated in Reais here as opposed to dollars because these were statutorily defined.

${ }^{6}$ See the relevant legislation in Ministério da Fazenda (2009).
} 
profits); Contribução para o Financiamiento da Seguridade Social - COFINS (social security contribution); and Contribução para a Seguridade Social a cargo de Pessoa Jurídica (employers' social security contributions). While value added taxes collected at the state and municipal levels - the Imposto Sobre Circulação de Mercadorias e Prestação de Serviços (ICMS) and the Imposto Sobre Serviços (ISS) - were initially not included in SIMPLES, states and municipalities could enter into agreements with the Federal Government to transfer to the latter the collection of the corresponding taxes through an increase in the SIMPLES rates.

In total, SIMPLES permitted an overall reduction of up to $8 \%$ in the tax burden faced by eligible firms (Monteiro and Assunção, 2006). Moreover, the new system also allowed substituting a fixed (and relatively low) percentage of total revenues for the standard payroll contribution, which led to a substantial reduction in labor costs and hence created a strong incentive to hire new employees and/or legalize already existing labor relationships (see González, 2006). The motivation behind the reductions in direct and indirect taxes achieved through SIMPLES was to enable small, unskilled laborintensive firms to compete more effectively with larger enterprises for which high tax burdens are more manageable due to scale economies. SIMPLES, however, explicitly excluded from program eligibility all activities that by law require the employment of professionals with regulated occupations. Examples of ineligible activities include the manufacturing of chemical products, machinery and equipment, as well education and health services. Incorporated companies were also not eligible for SIMPLES, nor were firms with government or foreign ownership, and firms operating in some selected sectors including financial services, real estate, private security, warehousing, and the manufacture of tobacco and beverages.

\section{Data}

We employ the Brazilian Survey of the Urban Informal Sector (Pesquisa Economia Informal Urbana, ECINF) collected in 1997 and 2003 by the Brazilian Statistical Institute (IBGE, Instituto Brasileiro de Geografia e Estadística). The ECINF 
offers extensive detail on the main firm and entrepreneur characteristics of Brazilian micro-enterprises such as sector, revenues, profits, employment size, capital stock and time in business. This survey generates cross-section data representative of all the urban self-employed and micro-firm owners with at most five paid employees, excluding domestic workers. The stratified sampling design (in two stages) allows studying a population of units which are rare, heterogeneous and hard to detect in standard household surveys. Geographically, it covers all of the 26 Brazilian states, as well as the Federal District, and also each of the 10 Metropolitan Areas (Belém, Fortaleza, Recife, Salvador, Belo Horizonte, Vitória, Rio de Janeiro, São Paulo, Curitiba and Porto Alegre) and the municipality of Goiânia. In each of its two waves, ECINF interviewed roughly 50,000 households among which it found more than 40,000 individuals which reported owning a micro-enterprise. As explained below, for the purpose of assessing the local impact of SIMPLES on formality rates we focus only on data from the ECINF 1997 and the statistics in this section correspond to 1997, except when indicated.

The most frequent sectors of activity are retail trade (26\% of micro-firms) and personal services (20\%), followed by construction (15\%), technical and professional services (11\%) and manufacturing (11\%). Respectively $8 \%$ and $7 \%$ of micro-firms belong to the sectors of hotels and restaurants, and transportation. Most firms are very small both in terms of revenues and employment: the average and median monthly revenues of Brazilian micro-firms were \$US 1,083 and \$US 600, respectively. We find that $87 \%$ of all Brazilian micro-firms have no paid employees, and $79 \%$ have no employees or partners at all. As reported in table 1, 10\% of the surveyed micro-firms have one or two paid employees, and only 3\% have between 3 and 5 paid workers. In those firms with at least one paid employee, roughly $22 \%$ of all workers are family members, almost two thirds of paid workers are non-registered - sem carteira assinada and only 35\% pay from social security contributions.

Table 2 shows that individuals that became entrepreneurs to escape from unemployment are found less frequently among the owners of firms with operating licenses (19\%) than among those without licenses (27\%). Similarly, among licensed 
formal enterprise owners there are fewer who report having started up to complement their family's income (12\% of licensed firms and $20 \%$ of non-licensed), and more among those that mention independence as the main reason to start their business (27 vs. $18 \%$ ). A higher fraction of licensed enterprises have plans to expand (44 vs. 36\%) and a lower number intend to abandon their business to search for salaried jobs (7 vs. 14\%). These responses are consistent with better quality entrepreneurs - those who had a choice about entering for example - being more likely to be formal.

Table 2 also shows that $85 \%$ of those firms that did not have a license at the time of the survey made no attempt to regularize at the time of starting up. ${ }^{7}$ In contrast, $75 \%$ of licensed entrepreneurs did at least try to regularize their firm when they began operating. Thus, the decision of whether to operate formally or informally appears to be made in most cases at the time of startup. To the extent that the decision to operate informally is based on a rational cost-benefit analysis, this suggests that for most firms the former exceed the latter. ${ }^{8}$ As discussed earlier, this could be due either to costly and/or complex registration procedures, to high tax rates, or to a limited demand among very small businesses for the government services. While the data do not allow us to distinguish among these different explanations, $72 \%$ of the firms that do attempt to register report having no difficulties in the process. Barriers to registration are not the principle drivers of informality.

Overall, table 3 shows that formality rates are low. As in other countries, obtaining a business license issued by either the state or the municipal government is a basic legal requirement for operating as a formal business in Brazil and also for issuing official invoices for tax purposes. Still, only about $23 \%$ of micro-firms are licensed. Moreover, less than $15 \%$ are established legal entities, $11 \%$ are formally registered as micro-enterprises, and $13 \%$ are registered with the tax authority. ${ }^{9}$ Only $7 \%$ and $8 \%$ of all

\footnotetext{
${ }^{7}$ This question is available only in the ECINF 2003.

${ }^{8}$ We are grateful to an anonymous referee for pointing this out.

${ }^{9}$ Only those firms that were registered as legal entities answered subsequent questions about micro-firm registration and registration with the tax authorities. In 1997, ECINF asked for the Registro no Cadastro Geral de Contribuintes (the general tax registry) and the respondent had to provide their number or select the options: "not registered", "unknown" or "not applicable". The registration with the tax authority
} 
firms report paying taxes or making social security contributions, respectively. In general, formality rates are about three times higher among firms with at least one employee (besides the owner).

The ECINF survey shows that the entrepreneurs working in the micro-firm sector have very low levels of human capital. Close to $8 \%$ has no formal instruction and $60 \%$ has only primary school education levels. The average age is 40 years old and $34 \%$ are female. In the following sections we only consider the sample of entrepreneurs aged 20 to 65 who are not college graduates. The idea is to focus on working age individuals and to exclude micro-firms dedicated to the provision of professional services (e.g. doctors, lawyers, etc.).

\section{Preliminary data analysis}

Figures 1-6 graphically offer a first pass at the impact of SIMPLES on six dimensions of formality. These are plotted on the vertical axis against time in business. ${ }^{10}$ We restrict the sample to firms that were started during the period between February 1996 and October 1997. Thus, our time in business variable varies between 0, for firms created during the month in which ECINF was fielded, and 20 for firms created 9 months prior to SIMPLES. We plot the formality rates across these 21 months for both eligible (left panel) and non-eligible (right panel) firms. For illustrative purposes, we fit a cubic polynomial to the formality rates observed among firms of different ages (months in business), allowing for a break before and after November 1996 (respectively to the right and left of the vertical line in each panel).

variable is a dummy variable that has a value of 1 if the respondent provides the number or declare it to be unknown, and 0 otherwise.

${ }^{10}$ The ECINF asks whether respondents started their firms themselves or became owners at a later date. The survey then collects data on the number of years and months since respondents respectively started the firm or became owners-partners. We use this information to construct our time-in-business variable. For firms that were not started by their current owners, our time-in-business variable reflects the time since the current owner joined in as a partner, which is not necessarily the actual age of the firm. This problem, however, affects only $8 \%$ of firms (92\% of respondents report having started their own firms) and it does not appear to have a significant impact on our main conclusions. Indeed, when we exclude from the sample the $8 \%$ of firms which were not started by their current owners, our estimation results remain virtually unchanged. 
With the exception of social security payments, formality rates are higher for eligible firms that started their operations between November 1996 (the month in which SIMPLES was launched, marked with a vertical line) and January 1997 compared with the rates prevailing among firms that were started during the previous three-month period. That is, there is evidence of an important discontinuity which we can exploit. The largest jump is found for licensing rates (figure 1) which increase by about $50 \%$ between the three months prior to SIMPLES and the three months that followed. However, increases of roughly $30 \%$ are also observed in the likelihood of firms being registered as legal entities, as micro-firms or as tax payers, and that of reporting at least some tax payments (figures 2 to 5). Comparable jumps are not observed among non-eligible firms. As an example, comparing the 9-months periods prior and following SIMPLES, the incidence of licensing among eligible firms increased from 20.8 to $25.3 \%{ }^{11}$ For noneligible firms the increase was only from 25.2 and $26.8 \%{ }^{12}$

Finally, formality rates tend to increase with firm age, consistent with entrepreneurs having had more time to assess their business prospects (and whether formalization is worthwhile) and also more time to complete the procedures required for regularization.

A striking feature of the data is that SIMPLES does not appear to have a permanent effect on the share of firms registered. Firms born after the date of introduction appear to have progressively lower rates of registration. This might be due to other factors that independently shifted down the rate of registration in the economy overall. Alternatively, it might also that other temporary programs, such as the

\footnotetext{
${ }^{11}$ Compared to the samples in Figures 1 through 6 we exclude those firms created from August 1997 to October 1997 (i.e. 0 to 2 months before ECINF) as these firms may not have had enough time to complete the procedures required for formalization.

${ }^{12}$ One concern is that these changes may be purely capturing differential seasonal effects .To rule this out, we compute the same above percentages for a window generated one year before, as if SIMPLES would have been implemented in November 1995 instead of 1996. In this case eligible firms show licensing rates from 20.3 to $22 \%$ for before and after respectively, and non-eligible rates are 24 to $25.9 \%$ for before and after respectively. The effect is far smaller for the eligible than what we find in the true SIMPLES period. Similar results can be obtained by using different years.
} 
widespread information campaign that accompanied the introduction of SIMPLES but which were later discontinued, drive the effect that we observe rather than the costs of formality per se. Finally, the tax reduction benefits associated with registering in SIMPLES were arguably higher for those firms that opted for the system before April 1997 and this may also cause the differential impact. ${ }^{13}$ For our purposes, the reason for the decay is not important. It is the existence of the jump or discontinuity that helps us identify the effect of formality, whatever the cause, on firm performance.

\section{Estimating the Impact of Formality on Performance}

\section{Va. Econometric Model}

In a general linear regression set-up, a firm performance variable $Y$ can be expressed as

$$
Y_{i}=\beta_{1} D_{i}+\beta_{2} t_{i}+\beta_{3} X_{i}+\theta_{i}+u_{i}
$$

where $i$ denotes the firm, $D$ is a binary formality indicator, $t$ denotes time in business, $X$ is a set of exogenous covariates, $\theta$ is a firm-specific unobserved component, and $u$ is an idiosyncratic error component. Consistent with the program evaluation literature, we will

\footnotetext{
${ }^{13}$ The law established that firms could opt for using SIMPLES - instead of complying separately with the various taxes and contributions for which the new system substituted - either at the time of registering with the tax authority, or by means of an alteration in their existing tax registration. After enrolling in the program, SIMPLES would become effective on the first day of the following calendar year. However, during the first year of the program SIMPLES became effective retroactively on January $1^{\text {st }}$ of 1997 for all firms enrolled by March $31^{\text {st }}$. As a result, the incentives for enrolling in the program were arguably higher during the first quarter of 1997 than during the remainder of that year. Indeed, the tax reduction benefits from SIMPLES would be virtually immediate for firms enrolled during that initial period. In contrast, for firms enrolled on or after April $1^{\text {st }} 1997$ the potential benefits from SIMPLES would be delayed until January $1^{\text {st }} 1998$ and, at least for informal firms, there could be immediate increases in tax payments associated with the need to register with the tax authority. It is worth noting, however, that the Law which created SIMPLES allowed firms with pending tax and social security obligations derived from activities undertaken prior to October $31^{\text {st }} 1996$ to work out a payment plan spanning up to 6 years. Arguably, this could create an added incentive to enroll in SIMPLES, even if for firms which enrolled after March 1997 tax reduction benefits would not take effect until January 1998.
} 
refer to $D$ as a treatment indicator and the parameter of interest, $\beta_{1}$, the treatment effect. As discussed in the introduction, in a naïve OLS framework estimates of $\beta_{1}$ are likely to be biased due to possible correlation between firms that receive the treatment and the unobserved component.

The introduction of SIMPLES by unanticipated administrative decree can be seen as an exogenous policy change that significantly altered the incentives to become formal and hence is useful in avoiding the possible biases arising from self-selection. Monteiro and Assunção (2006) take a difference-in-differences approach. To paraphrase, let AFTER be an indicator for whether a firm was created before or after the SIMPLES was implemented (such that $A F T E R_{i}=1$ if $t_{i} \leq \bar{t}$ and $A F T E R_{i}=0$ otherwise, where firms that have been in business for at most $\bar{t}$ months were created after SIMPLES) and ELIG an indicator for the eligibility status of the firm. Monteiro and Assunção (2006) use the interaction of eligible/non-eligible and before/after indicators (i.e. AFTER $\times E L I G$ ) as an instrument to measure the impact of formality on investment and credit access, with the first stage regression being as follows:

$$
D_{i}=\alpha_{1} E L I G_{i}+\alpha_{2} A F T E R_{i}+\alpha_{3}\left(E L I G_{i} \times A F T E R_{i}\right)+\alpha_{4} X_{i}+\varepsilon_{i}
$$

While this approach is conceptually sound, it may be giving relatively weak findings in the present context for three reasons. First, the decay in the impact of SIMPLES observed in figures 1-6 implies that SIMPLES's introduction is progressively less valid as an instrument the further away from the discontinuity the firm is born. Second, IV standards errors approach those of OLS only when there is a high degree of covariation of the instrument and the treatment indicator. This does not appear to be their case. Finally, there is some question about how well the non-eligible population serves as a control group. The 2003 ECINF included a question regarding whether firms that are legally constituted have used the SIMPLES. Whether due to misclassification of their activities, low law enforcement, or other clerical error, $55 \%$ of non-eligible firms declared to have used the SIMPLES. If not due to clerical or recall errors, this may 
weaken the validity of the instrument. Together, these factors may contribute to Monteiro and Assunção’s (2006) findings of an overall insignificant effect of SIMPLES.

We take two separate approaches. First, we adopt a RD approach that exploits the sample immediately around the introduction of SIMPLES and in principle, obviates the need for a control group. Second, we revisit the difference-in-differences approach, but adopt a RD weighting scheme that exploits the higher quality of the instrument near the introduction of SIMPLES and strengthens the instrument using additional covariates.

\section{Regression Discontinuity Approach}

The RD literature (see Hahn, Todd and Van der Klaauw, 2001 and Van der Klaauw, 2002) argues that a local estimate of treatment impact can be obtained by giving heavier weights to observations arbitrarily close to a discontinuity. If, conditional on a set of exogenous covariates, we assume very similar distributions of unobservable characteristics of firms born immediately before and after SIMPLES implementation, the discontinuity that the introduction of SIMPLES introduces in the factors determining formality can be exploited to provide unbiased estimates of the local average treatment effect of the program. ${ }^{14}$ In our case the discontinuity affects the probability of receiving the treatment. That is, we assume that $P\left[D_{i}=1 \mid t_{i}=t, X_{i}=x\right]=E\left[D_{i} \mid t_{i}=t, X_{i}=x\right]$ has a discontinuity at $t_{i}=\bar{t}$.

Estimating the coefficient $\beta_{1}$ in eq. (1) in the RD approach provides a local treatment effect:

$$
\beta_{1}(X=x)=\frac{\lim _{t \downarrow \bar{t}} E[Y \mid t, X=x, \text { elig }]-\lim _{t \uparrow \bar{t}} E[Y \mid t, X=x, e l i g]}{\lim _{t \downarrow \bar{t}} E[D \mid t, X=x, e l i g]-\lim _{t \uparrow \widehat{t}} E[D \mid t, X=x, e l i g]}
$$

\footnotetext{
${ }^{14}$ See Imbens and Angrist (1994) for a theoretical discussion on local vs. global treatment effects.
} 
This estimator can be obtained by an instrumental variables procedure where, instead of eq (2), D is instrumented by AFTER using the sample of eligible firms only and weights to amplify observations close to the cut-off around the date of the introduction of SIMPLES. We refer to this as the "Before and After" (BA) estimator.

A few comments are in order. First, the corresponding inference about the impact of formality is only valid in an arbitrary small interval around the date of SIMPLES introduction. As noted earlier, there is decay in the impact of SIMPLES that suggests that more than the cost reduction measures themselves may be at play. Again, while this clearly does affect how much we attribute an increase in formality to one factor or another, it does not prevent us from using the discontinuity to get unbiased estimates of the impact of formality on firm performance. However, we do need to focus only on the local effects of SIMPLES in the period immediately after its introduction. ${ }^{15}$

Second, strictly speaking, we really are not looking at the impact of formalization on existing informal firms, but rather asking "if this particular informal firm were reborn a couple of months later under the SIMPLES regime, how would its likelihood of registering be increased, and how would its performance vary as a result of registration?” Hence, the differences we observe in post-SIMPLES firm performance potentially reflect very different initial decisions about financing, mode of operation, and even technology that lead to very distinct development paths.

\section{Strengthening the Difference-in-Differences Approach}

We borrow two innovations that we introduced in the RD exercise to strengthen Monteiro and Assunção's approach of employing the ineligibles as a control group. First,

\footnotetext{
${ }^{15}$ It is worth noting that we are not per se interested in the local (short-run) vis-à-vis the global (or longrun) effects of SIMPLES. Our main interest is in obtaining unbiased estimates of the impact of formality on micro-firm performance. This requires finding an exogenous source of variation in formality rates, so as to deal, for example, with the likely reverse causality operating from firm performance to formality. While the introduction of SIMPLES allows us to deal with this endogeneity issue, we argue that it does so only in a local sense. In other words, the same approach cannot be used to estimate the global or long-run impact of SIMPLES, and we are not in a position to say whether that impact is or not significant.
} 
we interact the instruments with the age and gender of the entrepreneur, factors which are arguably exogenous. This reduces the IV standard errors to roughly one third of their original value. Moreover by artificially increasing the number of instruments we are able to test for the validity of instruments using the Sargan test. Second, we weight the instruments based on their closeness to the break-point. In effect, both approaches become RD with these weightings, only the second also exploits the information in the differential behavior of the ineligible sample, should this be reliable. We refer to this as the Difference-in-Differences (DD) estimator.

\section{Vb. Estimation Results}

The effect of SIMPLES on formality (first stage)

The effect of SIMPLES on formality on our six formality indicators is of interest both in itself and because, in a more parsimonious form, the regression eq. (2) constitutes the first step of the IV estimation. We also include as covariates $(X)$ measures of gender, age, and education of the firm's owner, number of household members, a set of dummy variables for the reasons that entrepreneurs reported for starting their micro-firms (see table 2), as well as state and industry dummy variables. We estimate this first for all micro-firms, and then for the subset of all firms with at least one employee (besides the owner). As is standard in this literature, we include a quadratic polynomial in time-inbusiness to control for potential biases coming from the functional form in the weighting scheme (see Van der Klaauw, 2002). The inclusion of this or higher order polynomials has little impact on the coefficient estimates.

We employ weighted least squares with a weight scheme based on a normal kernel with bandwidth of one month. ${ }^{16}$ As is customarily the case, choosing the bandwidth of the kernel involves tradeoffs of bias and variance. Increasing the bandwidth incorporates more observations and hence reduces the variance, but, by losing some of

\footnotetext{
${ }^{16}$ In this case, the bandwidth corresponds to the standard deviation in months used to standardize the difference in time in business with respect to the break-point of November 1996.
} 
the "localness" risks increasing bias. To check the sensitivity of our estimates, figures 7 and 8 present the RD and DD estimates of the specification used in table 4 below for licensing and legal entity, ${ }^{17}$ respectively, for the sample of all micro-firms, own-account workers, and firms with employees, across a bandwidth grid of $\{0.5,1,1.5, \ldots, 5\}$ months. As expected, the coefficients become less significant and smaller in magnitude as the bandwidth increases. Our preferred specification uses a bandwidth of 1 (i.e. a normal kernel with standard deviation of 1 month) because it yields the most statistically significant impact of SIMPLES.

Two sets of results are reported in table 4. The first corresponds to the BA estimates and reports the coefficient on AFTER from the sample of eligible firms, columns (1)-(3). Columns (4)-(6) correspond to the DD estimator and report the coefficient on AFTER $\times E L I G I B L E$ using the whole sample of eligible and non-eligible firms.

The results are broadly similar across the two estimators. The program led to an $11.6 \%$ and $7.1 \%$ percent increase in licensing rates for the RD and DD approaches respectively; an increase of $7.5 \%$ and $6.4 \%$ in the number of firms registered as formal legal entities; an increase of micro-firm registration of 6.3\% and 5.7\%; an increase in tax registration of $7.2 \%$ and $2.8 \%$ (not significant in DD); an increase in tax payments of $3.1 \%$ and $4.6 \%$; and an increase in social security contributions of $4.3 \%$ and $-.1 .4 \%$ (not significant in DD). The effect of SIMPLES on formality is often roughly twice as large in firms with employees, although the significance level is less consistent across formality measures.

In the interest of compactness, we only summarize here the results for the other covariates and do not report them. Across our measures, male, older and more educated entrepreneurs are more likely to be formal as are those who entered voluntarily and especially, because of family tradition. Retail trade, transportation and restaurants \&

\footnotetext{
${ }^{17}$ Although not reported, similar results are obtained for the remaining measures of formality in table 3.
} 
lodging have the highest formality rates, while manufacturing, construction and personal services have the lowest.

The effect of formality on firm performance (second stage)

Given the first stage results, we apply a weighted instrumental variable estimation (i.e. two stage least squares, W2SLS) procedure to get consistent estimates of the effect of formality. We pay particular attention to the IV F-test because, in general, there is a strong association between weak instruments in the first stage and larger standard errors in the second stage. Moreover, the validity of the IV inference relies on the significance of the instruments in the first stage. ${ }^{18}$

For licensing in the full sample, the F-tests of the instruments in the first stage are 4.75 and 4.80 for the BA and DD estimators, respectively. These are low and, therefore, we follow Stock and Yogo (2005) in employing a limited information maximum likelihood estimator (LIML) that is more robust to small-sample bias than is IV. We also report these results in tables 5 and 6 . Restricting the sample to firms with at least one employee gives F-tests of 9.65 and 11.27 for the BA and DD estimators respectively, which suggests that the instruments are sufficiently strong. The Sargan test of overidentification cannot reject the null hypothesis of exogeneity of the instruments.

Unfortunately, the instruments are weaker for the other measures of formality. For instance, the maximum F-test for legal entity is found for the DD estimator using the

\footnotetext{
${ }^{18}$ A recent literature (see e.g. Stock and Yogo, 2005; Staiger and Stock, 1997) contends that with weak instruments (i.e. low correlation between the endogenous regressors and instruments used to identify their coefficients) the asymptotic approximation of the limiting distribution of an IV estimator may be quite different from its small-sample distribution. Simplicity of using asymptotic approximations do not justify their use if the inaccurate inferences cannot be tolerated (e.g. if the inferences are to be used for policymaking). Staiger and Stock (1997) suggest that the rule of thumb for an instrumental variable to be sufficiently strong is to have a first stage F-test value of 10 . The literature prefers methods that (i) yield better approximations, (ii) allow transparency of inferences in terms of the expected bias from the use of one method versus another, and (iii) allow the use of diagnostics, for example, size of the test that one is willing to tolerate with weak instruments when using testing using an asymptotic approximation. An emerging consensus form this literature is the preference for the use of limited information maximum likelihood estimators over IV.
} 
sub-sample of firms with at least one employee, with a value of 4.77 , while for paying taxes it is 3.77 for the $\mathrm{RD}$ approach in the sample with all firms. ${ }^{19}$ In these cases, the instruments are generally too weak to yield reliable second stage estimates. We therefore restrict the analysis to the licensing variable going forward.

Tables 5 and 6 present the WLS, W2SL, and LIML results for licensing. ${ }^{20}$ For robustness we run them in logs and levels and, in addition, run a specification trimming the top $1 \%$ to control for possible outliers. We report only the coefficient of interest though all specifications include the same covariates used in the first stage (including a quadratic polynomial in time in business to capture non-linearity). Across all specifications, formalized firms show higher revenues and profits and significantly so. In the WLS estimates, they show 57\% and 55\% more revenue and $49 \%$ and $45 \%$ higher profits than non-licensed firms for the full sample in the BA and DD cases respectively. If only firms with employees are considered, the increase in revenues is $70 \%$ and $60 \%$ respectively, and profits $64 \%$ and $55 \%$ respectively. When converted to percentage changes, the results from the levels specifications are broadly similar. ${ }^{21}$ The results using the trimmed sample are reduced by about $10 \%$ in logs, and $20 \%$ in levels but they preserve the overall level of magnitude of previous estimates. Taken together, these rates of increase are similar to those found in Fajnzylber et al. (2009) estimates for the impact of formality in Mexico.

In general, when instrumented in the W2SLS specifications, the effect of licensing increases substantially in both approaches and by broadly similar amounts. The magnitude is impressive although the higher standard errors resulting from instrumenting really only allow us to confidently say that WLS was not biasing the estimates upward. That is, by constructing a 95\% confidence interval about the IV estimate (i.e. plus and

\footnotetext{
${ }^{19}$ The second stage for legal entity and paid taxes are not reported, but they are available from the authors upon request. In general, the coefficient estimates go in the same direction as those found in the licensing case but with considerably higher standard errors.

${ }^{20}$ The WLS estimates are based on equation (1) with weights based on the "distance" to the date of SIMPLES introduction.

${ }^{21}$ The weighted average monthly revenue is $\mathrm{R} \$ 1,145$ for all firms and $\mathrm{R} \$ 2,830$ for firms with at least one employee. This implies that the calculated percentage change is $75 \%$ for BA and $64 \%$ for DD using all firms, and $51 \%$ for BA and $44 \%$ for DD using firms with employees.
} 
minus the standard error times 1.96), we find that in general the lower bound is above or close to the WLS estimate. However, the large standard errors do not allow for further inference on the point estimate of the effect of licensing on revenues and profits. The fact that IV estimates are bigger than least squares suggests a negative correlation between $\theta$, the unobserved entrepreneurial ability, and licensing. Again, though many interpretations are possible, this is consistent with productive entrepreneurs remaining informal to avoid present or anticipated social security contributions.

\section{Vc. What are the Channels through which Formality Affects Firm Performance?}

The increases in revenues and profits estimated are quite large. What is it about becoming registered that is driving this? One possibility is suggested by recent experimental work by McKenzie and Woodruff (2008) in Mexico who find that releasing constraints on credit yields outsized returns of 20 to 33\% per month. The return is much higher (70-79\%) for firms that report being financially constrained. Further, as argued earlier, the desire to avoid very high labor costs may lead high productivity entrepreneurs to stay informal and their firms to be of substantially suboptimal size.

Tables 5 and 6 run the same specification as above but replacing revenue with intermediate firm performance indicators and characteristics such as employment, paid employment, the ratio of paid to total employment, fixed capital stock, whether or not the firm had access to credit, whether or not the firm had a fixed physical location, and whether or not it had sales to larger firms or the government.

In both samples of firms, formality led to an increase in employment of 0.4-0.5 employees in WLS, and roughly a doubling when instrumented. Particularly for firms with at least one employee, the implied increase in employment is substantial. Further, it also appears that this increase is largely in paid employees. Thus, we see between a 10 to $40 \%$ increase in the share of paid employees in employment. 
The capital stock results are less consistent across samples and estimation techniques. WLS suggests doubling in the full sample and perhaps $60-70 \%$ in the larger firm sample. However, the W2SL and LIML estimates for the overall sample are insignificant. For the larger firm sample, they suggest a tripling of the fixed capital stock. Surprisingly, this does not appear to be occurring as a result of access to credit, a dummy variable for firms that have received a credit from a bank or lending institution in the year before October 1997. While the WLS results in the small sample suggest a rise of roughly $20 \%$ in access to credit, once instrumented the impact becomes insignificant. In the larger firm sample, the coefficients actually suggest a fall of up to $20 \%$. Nor is there evidence that formality led to increased sales to larger firms which might have offered a different source of capital. ${ }^{22}$ What we do see that may explain the higher capital stock is a $30-50 \%$ increase in the probability of having a fixed physical location for the whole sample in WLS, and for all estimations in the larger firm sample.

In pulling these results together, again, it is important to remember that we are not thinking of existing firms suddenly doubling their capital or labor force upon registering. Rather, the experiment is to rerun the firm's development if they had registered at the beginning. The results suggest that the big gain is through the choice of a permanent location which permits an expansion of capital and employment. That is, entrepreneurs appear to choose a different scale and arguably, technology of production, even type or quality of product when they register their firm at the time of start up, than if they do not.

\section{Conclusions}

The quasi-experiment offered by the implementation of the SIMPLES program in Brazil suggest that it is possible to increase levels of registration by non trivial amounts and that this, in turn, leads to much higher revenues, employment and profits among

\footnotetext{
${ }^{22}$ As pointed out by an anonymous referee, at the time of the introduction of SIMPLES, the program did not include the VAT. Thus, larger firms have no incentive to buy from micro-firms enrolled in SIMPLES, as they cannot claim tax credits for the taxes paid to those firms. Therefore we cannot test the hypothesis in De Paula and Scheinkman (2007), although we can still study whether formality per se allow small firms to gain access to larger clients.
} 
firms which register as a result. Which dimension of the SIMPLES program is behind these effects- whether reduced registration costs, reductions in the number of transactions or the overall level of taxation on labor - is not clear. In fact, SIMPLES appears to have had a very local impact on formality decisions. This could be due to its particular implementation design, or it may reflect that other SIMPLES-related factors, such as the information campaign that surrounded its launching, were necessary complements.

The channels through which performance increased appear not to arise from access to credit or access to larger clients. Rather, we see a rise in the likelihood that the firm with have a fixed locale, and large increases in labor contracted formally. This suggests that the reductions in social security payments for hired labor were central-the lower amounts made firms more willing to register workers, and hence made them less concerned about detection. The result appears to be that firms born under SIMPLES adopted production technologies and lines of business that were more permanent, capital intensive, and of a larger scale, as measured by number of employees. 


\section{References}

Almeida, R, Carneiro, P. Enforcement of labor regulation, informal labor, and firm performance. World Bank Policy Research Working Paper 3756; 2005.

Bruhn, M. License to sell: the effect of business registration reform on entrepreneurial activity in Mexico. World Bank Policy Research Working Paper Series 4538; 2008.

De Paula, A, Scheinkman, J. The informal sector. NBER Working Paper 13486; 2007.

De Soto, H. The other path: The invisible revolution in the Third World. Harper and Row: New York; 1989.

Fajnzylber, P, Maloney, W F, Montes-Rojas, G. Releasing constraints to growth or pushing on a string? Policies and performance of Mexican micro-firms. Journal of Development Studies 2009; forthcoming.

Farrell, D. The hidden dangers of the informal economy. McKinsey Quarterly 3; 2004.

Gërxhani, K. The informal sector in developed and less developed countries: a literature survey. Public Choice 2004;120;267-300.

González, D. Regímenes especiales de tributación para pequeños contribuyentes en América Latina. Banco Interamericano de Desarrollo; 2006. Site: http://www.eurosocialfiscal.org/uploads/documentos/20081031_131029_Regimenes_ especiales_de_Tributacion_2006.pdf

Hahn, J, Todd, P, Van der Klaauw, W. Identification and estimation of treatment effects with a regression-discontinuity design. Econometrica 2001; 69; 201-209.

Heckman, J, Pagés, C. Law and employment. Lessons for Latin America and the Caribbean. The University of Chicago Press: London; 2004. 
Imbens, G W, Angrist, J D. Identification and estimation of local average treatment effects. Econometrica 1994;62;467-475.

Kaplan, D, Piedra, E, Seira, E. Are burdensome registration procedures an important barrier on firm creation? Evidence from Mexico." SIEPR Discussion Paper 06-13; 2006.

Levenson, A R, Maloney, W F. The informal sector, firm dynamics and institutional participation. World Bank Policy Research Working Paper 1988; 1998.

Loayza, N V, Oviedo, A M, Serven, L The impact of regulation on growth and informality - cross-country evidence. World Bank Policy Research Working Paper 3623; 2005.

Ministério da Fazenda; 2009. Site: http://www.receita.fazenda.gov.br/legislacao/legisassunto/Simples.htm

McKenzie, D, Woodruff, C. Do entry costs provide an empirical basis for poverty traps? Evidence from Mexican microenterprises. Economic Development and Cultural Change 2006; 55; 3-42.

McKenzie, D, Woodruff, C. Experimental evidence on returns to capital and access to finance in Mexico. World Bank Economic Review 2008;22;457-482.

Monteiro, J C M, Assunção, J J. Outgoing the shadows: Estimating the impact of bureaucracy simplification and tax cut on formality and investment. European Meeting of the Econometric Society 2006; Vienna. Site:

http://www.eea-esem.com/files/papers/EEA-ESEM/2006/2089/ESEM\%202006\%20\%20Monteiro\%20and\%20Assuncao\%202005\%20-

\%200utgoing\%20the\%20shadows.pdf 
Staiger D, Stock J H. Instrumental variables regression with weak instruments. Econometrica 1997; 65; 557-586.

Stock J H.; Yogo M. Testing for weak instruments in linear IV regression. In: Andrews D W K, Stock J H (Eds), Identification and inference in econometric models: essays in honor of Thomas J. Rothenberg. Cambridge University Press: Cambridge; 2005.

Van der Klaauw, W. Estimating the effect of financial aid offers on college enrollment: A regression-discontinuity approach. International Economic Review 2002; 43; 12491287. 
Table 1: Size Distribution and Employment Composition of Brazilian MicroEnterprises

\begin{tabular}{ccccc}
\hline \hline \# Paid Employees & $\begin{array}{c}\text { Share of Micro- } \\
\text { firm Sector (\%) }\end{array}$ & $\begin{array}{c}\text { Family } \\
\text { workers/ Total } \\
\text { workers (\%) }\end{array}$ & $\begin{array}{c}\text { Informal } \\
\text { workers / Paid } \\
\text { workers (\%) }\end{array}$ & $\begin{array}{c}\text { Pay social } \\
\text { security (\%) }\end{array}$ \\
\hline 0 & 86.6 & 4.0 & - & 7.1 \\
1 & 7.4 & 21.2 & 71.6 & 27.0 \\
2 & 3.0 & 22.0 & 58.8 & 37.8 \\
3 & 1.6 & 22.1 & 52.8 & 49.3 \\
4 & 1.0 & 23.6 & 43.8 & 53.2 \\
5 & 0.5 & 18.9 & 44.7 & 49.4 \\
\hline \hline
\end{tabular}

Notes: ECINF 1997. Calculated using sample weights.

Table 2: Reasons for Starting-up, Firm Prospects and Firm Licensing

\begin{tabular}{|c|c|c|c|c|c|c|c|}
\hline $\begin{array}{l}\text { Main reason to start } \\
\text { a micro-firm }\end{array}$ & $\begin{array}{l}\text { \% firms } \\
\text { (with } \\
\text { License) }\end{array}$ & $\begin{array}{l}\% \text { firms } \\
\text { (without } \\
\text { License) }\end{array}$ & $\begin{array}{l}\% \\
\text { firms }\end{array}$ & Plans for Future & $\begin{array}{l}\text { \% firms } \\
\text { (with } \\
\text { License) }\end{array}$ & $\begin{array}{l}\% \text { firms } \\
\text { (without } \\
\text { License) }\end{array}$ & $\begin{array}{c}\% \\
\text { firms }\end{array}$ \\
\hline Didn't find a job & 18.9 & 27.4 & 25.4 & Expand & 44.3 & 35.5 & 37.5 \\
\hline Profitable business & 2.2 & 1.5 & 1.7 & & 30.1 & 30.0 & 30.0 \\
\hline Flexible hours & 1.6 & 2.3 & 2.1 & $\begin{array}{l}\text { Change activity, } \\
\text { remain } \\
\text { independent }\end{array}$ & 9.0 & 9.4 & 9.3 \\
\hline Be independent & 27.0 & 18.2 & 20.3 & Find a salaried job & 6.7 & 13.6 & 12.0 \\
\hline Family tradition & 10.9 & 7.5 & 8.3 & Don't know & 7.3 & 9.1 & 8.7 \\
\hline $\begin{array}{l}\text { To help family } \\
\text { income }\end{array}$ & 11.8 & 20.0 & 18.1 & $\begin{array}{l}\text { Difficulties to } \\
\text { regularize when } \\
\text { starting-up? } \\
(2003)\end{array}$ & $\begin{array}{l}\text { \% firms } \\
\text { (with } \\
\text { License) }\end{array}$ & $\begin{array}{l}\text { \% firms } \\
\text { (without } \\
\text { License) }\end{array}$ & $\begin{array}{c}\% \\
\text { firms }\end{array}$ \\
\hline $\begin{array}{l}\text { Accumulated } \\
\text { experience }\end{array}$ & 9.3 & 8.3 & 8.5 & Yes & 18.0 & 5.1 & 8.2 \\
\hline Make good deal & 8.3 & 8.2 & 8.2 & No & 57.4 & 10.4 & 21.7 \\
\hline As a secondary job & 2.1 & 2.0 & 2.0 & Didn’t Try & 24.7 & 84.5 & 70.1 \\
\hline
\end{tabular}

Notes: ECINF 1997 (except for "Difficulties to regularize when starting-up?" from ECINF 2003). Calculated using sample weights. 
Table 3: Formality Indicators for Brazilian Micro-Enterprises

\begin{tabular}{l|c|c|}
\hline \hline & All micro-firms (\%) & At least one employee (\%) \\
\hline License to operate & 23.2 & 31.1 \\
Legal Entity & 14.4 & 42.6 \\
Micro-firm Registration & 11.3 & 33.7 \\
Registered with Tax & & \\
Authorities & 13.0 & 39.1 \\
Paid Taxes & 6.7 & 17.0 \\
Paid social security & 7.9 & 24.8 \\
\hline \hline
\end{tabular}

Notes: ECINF 1997. Calculated using sample weights. 
Table 4: First stage results: Effect of SIMPLES on Formality

\begin{tabular}{|c|c|c|c|c|c|c|}
\hline & \multicolumn{3}{|c|}{$\begin{array}{c}\text { Eligible firms } \\
\text { Before-after } \\
\text { (AFTER) } \\
\end{array}$} & \multicolumn{3}{|c|}{$\begin{array}{c}\text { All micro-firms } \\
\text { Difference-in-differences } \\
\text { (AFTER } \times \text { ELIG) }\end{array}$} \\
\hline & $\begin{array}{l}\text { All micro- } \\
\text { firms }\end{array}$ & $\begin{array}{l}\text { Own- } \\
\text { account } \\
\text { workers }\end{array}$ & $\begin{array}{c}\text { At least } \\
\text { one } \\
\text { employee } \\
\end{array}$ & $\begin{array}{l}\text { All micro- } \\
\text { firms }\end{array}$ & $\begin{array}{l}\text { Own- } \\
\text { account } \\
\text { workers }\end{array}$ & $\begin{array}{l}\text { At least } \\
\text { one } \\
\text { employee }\end{array}$ \\
\hline License to operate & $\begin{array}{c}0.116^{* * * *} \\
(0.034)\end{array}$ & $\begin{array}{c}0.126 * * * \\
(0.038)\end{array}$ & $\begin{array}{c}0.074 \\
(0.068) \\
\end{array}$ & $\begin{array}{l}0.071^{*} \\
(0.040)\end{array}$ & $\begin{array}{c}0.031 \\
(0.044) \\
\end{array}$ & $\begin{array}{l}0.222 * * \\
(0.090)\end{array}$ \\
\hline Legal Entity & $\begin{array}{c}0.075^{* * *} \\
(0.022)\end{array}$ & $\begin{array}{c}0.041^{* *} \\
(0.019) \\
\end{array}$ & $\begin{array}{c}0.129 * * \\
(0.051) \\
\end{array}$ & $\begin{array}{c}0.064^{* *} \\
(0.027) \\
\end{array}$ & $\begin{array}{c}0.025 \\
(0.022) \\
\end{array}$ & $\begin{array}{c}0.193^{* * *} \\
(0.072) \\
\end{array}$ \\
\hline $\begin{array}{l}\text { Micro-Firm } \\
\text { Registration }\end{array}$ & $\begin{array}{c}0.063^{* * *} \\
(0.020) \\
\end{array}$ & $\begin{array}{c}0.028^{*} \\
(0.017) \\
\end{array}$ & $\begin{array}{c}0.126^{* *} \\
(0.053)\end{array}$ & $\begin{array}{c}0.057 * * \\
(0.025)\end{array}$ & $\begin{array}{c}0.038^{* *} \\
(0.020) \\
\end{array}$ & $\begin{array}{c}0.101 \\
(0.072)\end{array}$ \\
\hline $\begin{array}{l}\text { Registered with Tax } \\
\text { Authorities }\end{array}$ & $\begin{array}{c}0.072^{* * *} \\
(0.022)\end{array}$ & $\begin{array}{c}0.049 * * \\
(0.019)\end{array}$ & $\begin{array}{c}0.116^{* *} \\
(0.051)\end{array}$ & $\begin{array}{c}0.028 \\
(0.025)\end{array}$ & $\begin{array}{c}0.010 \\
(0.021)\end{array}$ & $\begin{array}{c}0.118 \\
(0.072)\end{array}$ \\
\hline Paid Taxes & $\begin{array}{c}0.031^{* *} \\
(0.016)\end{array}$ & $\begin{array}{c}0.041^{* *} \\
(0.016)\end{array}$ & $\begin{array}{c}-0.0011 \\
(0.039)\end{array}$ & $\begin{array}{c}0.046^{* *} \\
(0.019)\end{array}$ & $\begin{array}{l}0.039 * * \\
(0.018)\end{array}$ & $\begin{array}{l}0.093^{*} \\
(0.053)\end{array}$ \\
\hline Paid Social Security & $\begin{array}{c}0.043^{* * *} \\
(0.015)\end{array}$ & $\begin{array}{l}0.0069 \\
(0.010)\end{array}$ & $\begin{array}{c}0.128 * * * \\
(0.043)\end{array}$ & $\begin{array}{l}-0.014 \\
(0.018)\end{array}$ & $\begin{array}{c}-0.037^{* *} \\
(0.013)\end{array}$ & $\begin{array}{c}0.023 \\
(0.057)\end{array}$ \\
\hline
\end{tabular}

Notes: * Statistically significant at $1 \%, * * 5 \%, * * * 10 \%$. Standard errors in parenthesis. Columns (1)-(3): coefficient of AFTER is reported, sample of only eligible firms. Columns (4)-(6): coefficient of AFTER $\times$ ELIGIBLE is reported, sample of both eligible and non-eligible firms. All samples were constructed using ECINF 1997, composed of firms 3-20 months old, with entrepreneurs aged 20-65 years old and without college degree. Weighted Least Squares estimates with weights based on time in business using a normal kernel with a standard deviation (i.e. bandwidth) of one month, where firms born in November 1996 have a $\mathrm{Z}$ value 0 . 
Table 5: Impact of Formality (License to operate) on Firm Performance - All micro-firms

\begin{tabular}{|c|c|c|c|c|c|c|}
\hline & \multicolumn{3}{|c|}{$B A$} & \multicolumn{3}{|c|}{$D D$} \\
\hline & WLS & W2SLS & $\begin{array}{c}\text { W2SLS } \\
\text { LIML }\end{array}$ & W2SLS & W2SLS & $\begin{array}{l}\text { W2SLS } \\
\text { LIML }\end{array}$ \\
\hline Revenues (R\$) & $\begin{array}{c}859 * * * \\
(62)\end{array}$ & $\begin{array}{l}\text { 2277* } \\
(1305)\end{array}$ & $\begin{array}{c}2905 * * \\
(1638)\end{array}$ & $\begin{array}{c}735^{* * * *} \\
(61)\end{array}$ & $\begin{array}{c}3827 * * \\
(1558)\end{array}$ & $\begin{array}{c}4550 * * \\
(1851)\end{array}$ \\
\hline Revenues trimmed(§)(R\$) & $\begin{array}{c}661 * * * \\
(40)\end{array}$ & $\begin{array}{c}2238 * * * \\
(890)\end{array}$ & $\begin{array}{c}2408^{* *} \\
(959)\end{array}$ & $\begin{array}{c}597 * * * \\
(36)\end{array}$ & $\begin{array}{c}2984 * * * \\
(967)\end{array}$ & $\begin{array}{c}3291 * * * \\
(1083)\end{array}$ \\
\hline Revenues (log) & $\begin{array}{c}0.57 * * * \\
(0.04)\end{array}$ & $\begin{array}{c}3.21^{* * * *} \\
(1.03)\end{array}$ & $\begin{array}{c}3.59 * * * \\
(1.15)\end{array}$ & $\begin{array}{c}0.55^{* * * *} \\
(0.03)\end{array}$ & $\begin{array}{c}3.42 * * * \\
(1.04)\end{array}$ & $\begin{array}{c}3.68 * * * \\
(1.13)\end{array}$ \\
\hline Revenues (log) trimmed(§) & $\begin{array}{c}0.54 * * * \\
(0.04)\end{array}$ & $\begin{array}{c}3.21 * * * \\
(1.00)\end{array}$ & $\begin{array}{c}3.61 * * * \\
(1.15)\end{array}$ & $\begin{array}{c}0.54 * * * \\
(0.03)\end{array}$ & $\begin{array}{c}3.20 * * * \\
(0.96)\end{array}$ & $\begin{array}{c}3.58 * * * \\
(1.10)\end{array}$ \\
\hline Profits (R\$) & $\begin{array}{c}279 * * * \\
(27)\end{array}$ & $\begin{array}{c}468 \\
(562)\end{array}$ & $\begin{array}{c}474 \\
(571)\end{array}$ & $\begin{array}{c}259 * * * \\
(24)\end{array}$ & $\begin{array}{c}670 \\
(534)\end{array}$ & $\begin{array}{c}673 \\
(536)\end{array}$ \\
\hline Profits (log) & $\begin{array}{c}0.49 * * * \\
(0.04)\end{array}$ & $\begin{array}{c}2.69 * * * \\
(0.95) \\
\end{array}$ & $\begin{array}{c}3.26 * * * \\
(1.19) \\
\end{array}$ & $\begin{array}{c}0.45^{* * *} \\
(0.03) \\
\end{array}$ & $\begin{array}{c}2.77^{* * *} * \\
(0.97) \\
\end{array}$ & $\begin{array}{c}3.32^{* * *} \\
(1.19) \\
\end{array}$ \\
\hline Employment & $\begin{array}{c}0.398 * * * \\
(0.024)\end{array}$ & $\begin{array}{l}1.03^{* *} \\
(0.514)\end{array}$ & $\begin{array}{l}1.05^{* *} \\
(0.51)\end{array}$ & $\begin{array}{c}0.415^{* * *} \\
0.022\end{array}$ & $\begin{array}{c}1.29 * * \\
(0.535)\end{array}$ & $\begin{array}{l}1.44^{* *} \\
(0.60)\end{array}$ \\
\hline Paid Employment & $\begin{array}{c}0.26^{* * *} \\
(0.02)\end{array}$ & $\begin{array}{c}1.07^{* * *} \\
(0.43)\end{array}$ & $\begin{array}{c}1.19 * * * \\
(0.48)\end{array}$ & $\begin{array}{c}0.25^{* * *} \\
(0.02)\end{array}$ & $\begin{array}{c}1.10^{* * *} \\
(0.43)\end{array}$ & $\begin{array}{c}1.15^{* * * *} \\
(0.45)\end{array}$ \\
\hline Paid Employment / & & & & & & \\
\hline Employment & $\begin{array}{c}0.067 * * * \\
(0.005)\end{array}$ & $\begin{array}{c}0.25^{* * *} \\
(0.11)\end{array}$ & $\begin{array}{c}0.28 * * * \\
(0.12)\end{array}$ & $\begin{array}{c}0.064 * * * \\
(0.004)\end{array}$ & $\begin{array}{c}0.25^{* *} \\
(0.11)\end{array}$ & $\begin{array}{c}0.26^{* *} \\
(0.11)\end{array}$ \\
\hline Fixed Capital (log) & $\begin{array}{c}1.08^{* * *} \\
(0.109)\end{array}$ & $\begin{array}{r}1.08 \\
(2.17) \\
\end{array}$ & $\begin{array}{c}1.08 \\
(2.23) \\
\end{array}$ & $\begin{array}{l}1.07^{* * *} \\
(0.100)\end{array}$ & $\begin{array}{l}-0.166 \\
(2.28) \\
\end{array}$ & $\begin{array}{l}-2.01 \\
(2.45) \\
\end{array}$ \\
\hline Access to Credit & $\begin{array}{c}0.019 * * \\
(0.007)\end{array}$ & $\begin{array}{c}0.122 \\
(0.151)\end{array}$ & $\begin{array}{c}0.141 \\
(0.165)\end{array}$ & $\begin{array}{c}0.021 * * * \\
(0.007)\end{array}$ & $\begin{array}{l}-0.082 \\
(0.15)\end{array}$ & $\begin{array}{c}-0.138 \\
(0.185)\end{array}$ \\
\hline Fixed Location & $\begin{array}{c}0.21 * * * \\
(0.01)\end{array}$ & $\begin{array}{l}-0.010 \\
(0.23)\end{array}$ & $\begin{array}{l}-0.091 \\
(0.27)\end{array}$ & $\begin{array}{c}0.26 * * * \\
(0.01)\end{array}$ & $\begin{array}{c}0.0004 \\
(0.24)\end{array}$ & $\begin{array}{l}-0.011 \\
(0.25)\end{array}$ \\
\hline Sales to Firms & $\begin{array}{c}-0.016^{* *} \\
(0.008) \\
\end{array}$ & $\begin{array}{r}-0.133 \\
(0.174) \\
\end{array}$ & $\begin{array}{r}-0.147 \\
(0.184) \\
\end{array}$ & $\begin{array}{c}-0.023^{* * *} \\
(0.008) \\
\end{array}$ & $\begin{array}{c}0.080 \\
(0.181) \\
\end{array}$ & $\begin{array}{c}0.111 \\
(0.208) \\
\end{array}$ \\
\hline IV F-test & & & & & & \\
\hline
\end{tabular}

Notes: * Statistically significant at $1 \%, * * 5 \%$, *** $10 \%$. Standard errors in parenthesis. All samples were constructed using ECINF 1997, composed of firms 3-20 months old, with entrepreneurs aged 20-65 years old and without college degree. BA: before and after, sample of eligible firms only. DD: difference-indifferences, sample of both eligible and non-eligible firms. WLS: weighted least squares. W2SLS: weighted instrumental variables least squares (endogenous variable: License; instruments: AFTER interacted with Female and Age in columns 2 and 3, AFTER $\times$ ELIGIBLE interacted with Female and Age in columns 5 and 6). LIML: limited information maximum likelihood. Weights based on time in business using a normal kernel with a standard deviation (i.e. bandwidth) of one month, where firms born in November 1996 have a Z value 0. R\$: Brazilian Reais. One US dollar was equivalent to R\$1.1 in October 1997. (§) Sample is trimmed to $1 \%$ at the highest revenues. 
Table 6: Impact of Formality (License to operate) on Firm Performance - Firms with at least one employee (besides owner)

\begin{tabular}{l|c|c|c|c|c|c}
\hline & \multicolumn{3}{|c|}{$B A$} & \multicolumn{3}{c}{$D D$} \\
& & & $W 2 S L S$ & & & W2SLS \\
& WLS & W2SLS & LIML & W2SLS & W2SLS & LIML \\
\hline Revenues (R\$) & $1447^{* * *}$ & $3762^{* *}$ & $4203^{* * *}$ & $1253^{* * *}$ & $4288^{* * *}$ & $4776^{* * *}$ \\
& $(210)$ & $(1526)$ & $(1692)$ & $(178)$ & $(1322)$ & $(1462)$ \\
Revenues trimmed(§)(R\$) & $1034^{* * *}$ & $1481^{* *}$ & $1495^{* *}$ & $910^{* * *}$ & $2302^{* * *}$ & $2505^{* * *}$ \\
& $(112)$ & $(774)$ & $(786)$ & $(97)$ & $(689)$ & $(751)$ \\
Revenues (log) & $0.701^{* * *}$ & $1.94^{* * *}$ & $1.96^{* * *}$ & $0.603^{* * *}$ & $3.22^{* * *}$ & $2.62^{* * *}$ \\
& $(0.07)$ & $(0.54)$ & $(0.55)$ & $(0.06)$ & $(1.14)$ & $(0.56)$ \\
Revenues (log) trimmed(§) & $0.66^{* * *}$ & $1.69^{* * *}$ & $1.70^{* * *}$ & $0.57^{* * *}$ & $2.28^{* * *}$ & $2.38^{* * *}$ \\
& $(0.07)$ & $(0.49)$ & $(0.50)$ & $(0.06)$ & $(0.48)$ & $(0.51)$ \\
Profits (R\$) & $432^{* * *}$ & 447 & 447 & $365^{* * *}$ & $1000^{* *}$ & $1076^{*}$ \\
& $(88)$ & $(611)$ & $(615)$ & $(77)$ & $(533)$ & $(576)$ \\
Profits (log) & $0.64^{* * *}$ & $1.58^{* * *}$ & $1.66^{* * *}$ & $0.55^{* * *}$ & $1.94^{* * *}$ & $1.99^{* * *}$ \\
& $(0.07)$ & $(0.54)$ & $(0.57)$ & $(0.06)$ & $(0.50)$ & $(0.51)$ \\
\hline Employment & $0.473^{* * *}$ & $0.914^{* *}$ & $0.98^{* * *}$ & $0.413^{* * *}$ & $1.01^{* * *}$ & $1.30^{* * *}$ \\
& $(0.05)$ & $(0.36)$ & $(0.39)$ & $(0.05)$ & $(0.35)$ & $(0.45)$ \\
Paid Employment & $0.470^{* * *}$ & $1.65^{* * *}$ & $1.71^{* * *}$ & $0.385^{* * *}$ & $1.44^{* * *}$ & $1.51^{* * *}$ \\
& $(0.06)$ & $(0.45)$ & $(0.47)$ & $(0.05)$ & $(0.40)$ & $(0.42)$ \\
Paid Employment / & & & & & & \\
Employment & $0.095^{* * *}$ & $0.37^{* * *}$ & $0.39^{* * *}$ & $0.075^{* * *}$ & $0.30^{* * *}$ & $0.32^{* * *}$ \\
& $(0.014)$ & $(0.11)$ & $(0.11)$ & $(0.01)$ & $(0.10)$ & $(0.10)$ \\
Fixed Capital (log) & $0.67^{* * *}$ & $1.99^{*}$ & $2.41^{*}$ & $0.59^{* * *}$ & $2.50^{* *}$ & $2.94^{* *}$ \\
& $(0.21)$ & $(1.38)$ & $(1.60)$ & $(0.19)$ & $(1.28)$ & $(1.44)$ \\
\hline Access to Credit & -0.008 & -0.008 & -0.007 & 0.0024 & -0.171 & $-0.210^{* *}$ \\
Fixed Location & $(0.016)$ & $(0.11)$ & $(0.11)$ & $(0.015)$ & $(0.13)$ & $(0.115)$ \\
Sales to Firms & $0.31^{* * *}$ & $0.34^{* *}$ & $0.34^{* *}$ & $0.31^{* * *}$ & $0.51^{* * *}$ & $0.53^{* * *}$ \\
& $(0.03)$ & $(0.17)$ & $(0.18)$ & $(0.02)$ & $(0.16)$ & $(0.17)$ \\
& 0.0058 & -0.073 & -0.068 & 0.0099 & 0.050 & 0.056 \\
& $(0.018)$ & $(0.118)$ & $(0.129)$ & $(0.016)$ & $(0.108)$ & $(0.117)$ \\
\hline \hline
\end{tabular}

Notes: * Statistically significant at $1 \%, * * 5 \%, * * * 10 \%$. Standard errors in parenthesis. All samples were constructed using ECINF 1997, composed of firms 3-20 months old with at least one employee besides the owner, with entrepreneurs aged 20-65 years old and without college degree. BA: before and after, sample of eligible firms only. DD: difference-in-differences, sample of both eligible and non-eligible firms. WLS: weighted least squares. W2SLS: weighted instrumental variables least squares (endogenous variable: License; instruments: AFTER interacted with Female and Age in columns 2 and 3, AFTER $\times$ ELIGIBLE interacted with Female and Age in columns 5 and 6). LIML: limited information maximum likelihood. Weights based on time in business using a normal kernel with a standard deviation (i.e. bandwidth) of one month, where firms born in November 1996 have a Z value 0. R\$: Brazilian Reais. One US dollar was equivalent to $\mathrm{R} \$ 1.1$ in October 1997. (§) Sample is trimmed to $1 \%$ at the highest revenues. 
Figure 1: Proportion of licensed firms

\section{A. Eligible firms}

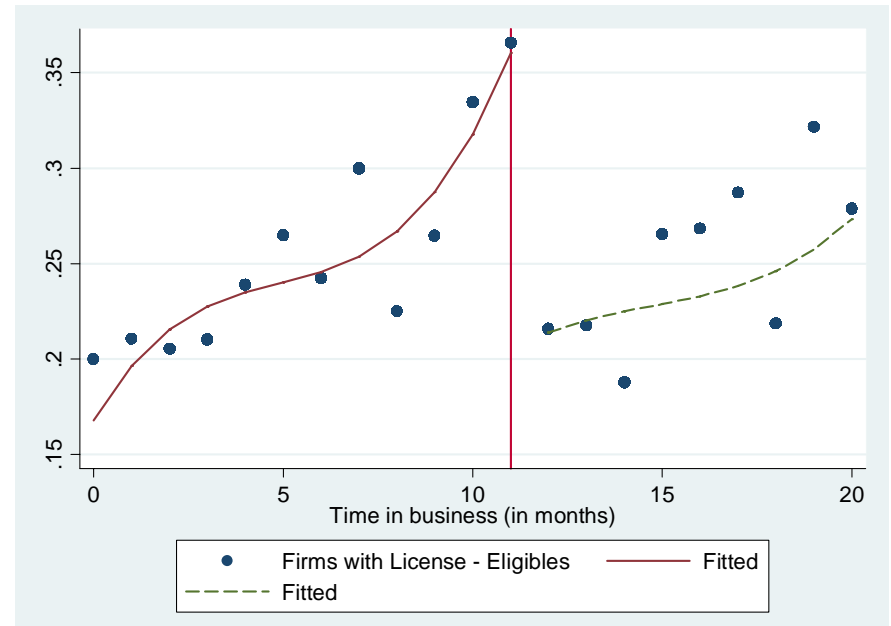

1B. Non-Eligible firms

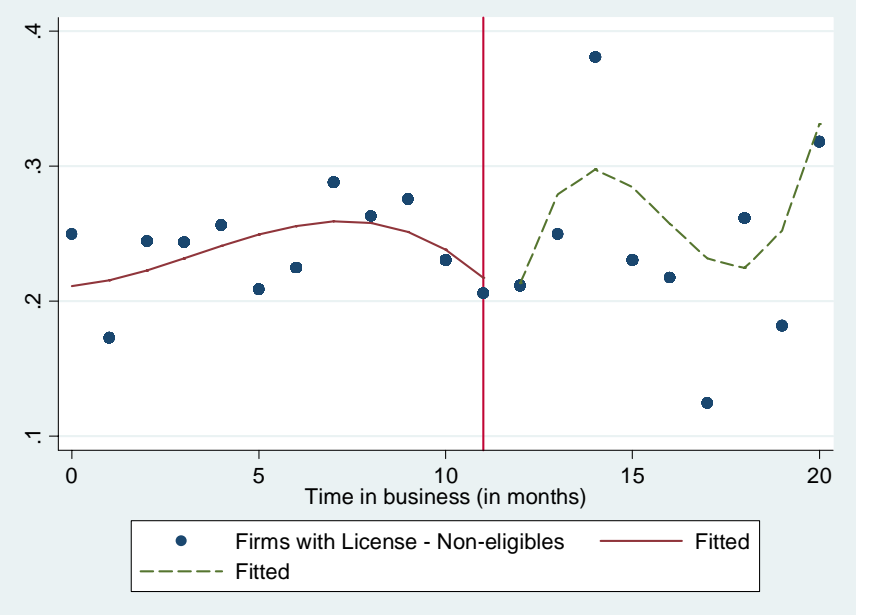

Notes: Authors' calculations using ECINF 1997 with firms born between February 1996 to October 1997. Entrepreneurs without college degree and 20-65 years old.

Figure 2: Proportion of firms established as legal entity

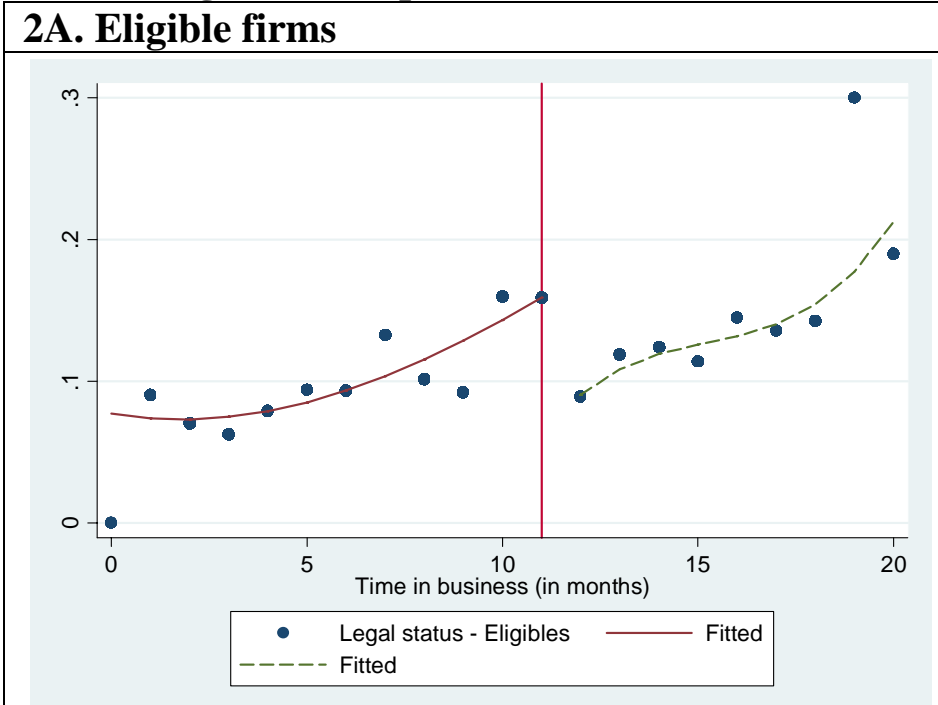

2B. Non-Eligible firms

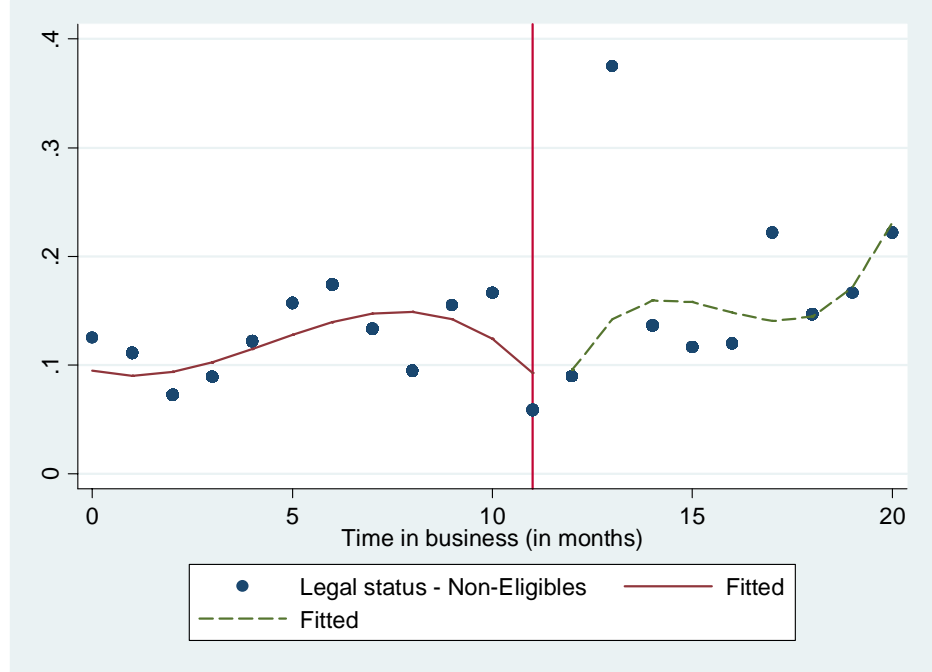

Notes: Authors' calculations using ECINF 1997 with firms born between February 1996 to October 1997. Entrepreneurs without college degree and 20-65 years old. 
Figure 3: Proportion of firms with micro-firm registration

\section{A. Eligible firms}

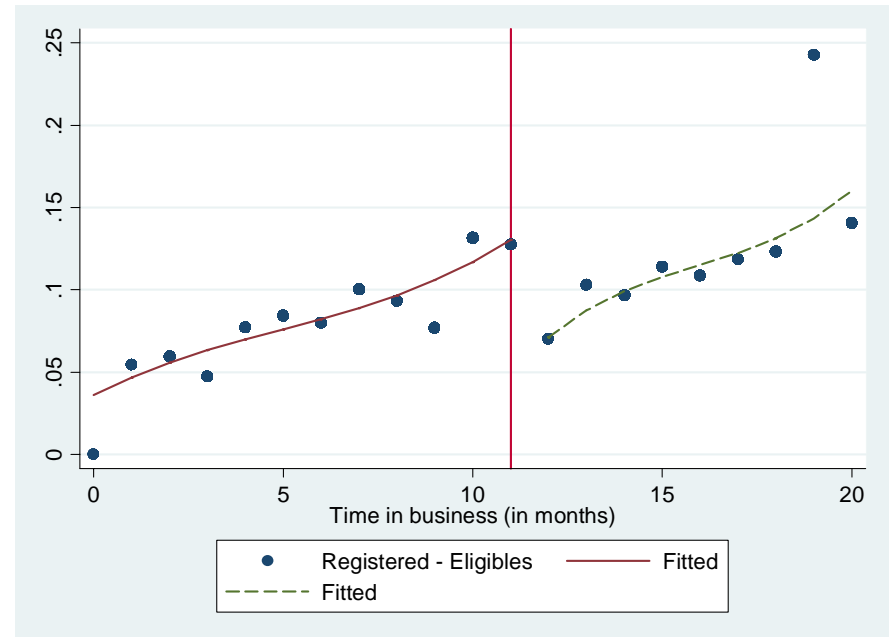

3B. Non-Eligible firms

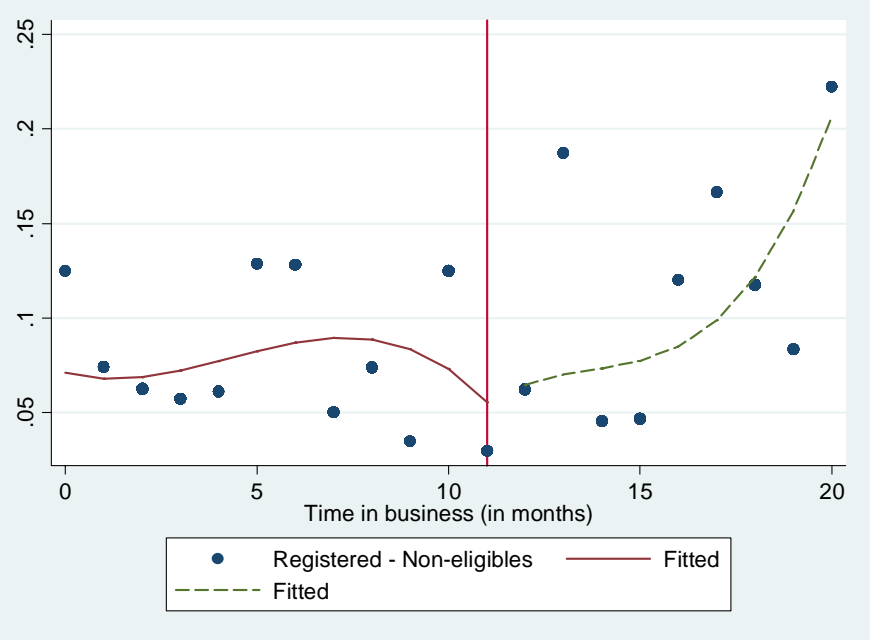

Notes: Authors' calculations using ECINF 1997 with firms born between February 1996 to October 1997. Entrepreneurs without college degree and 20-65 years old.

Figure 4: Proportion of firms registered with the tax authority

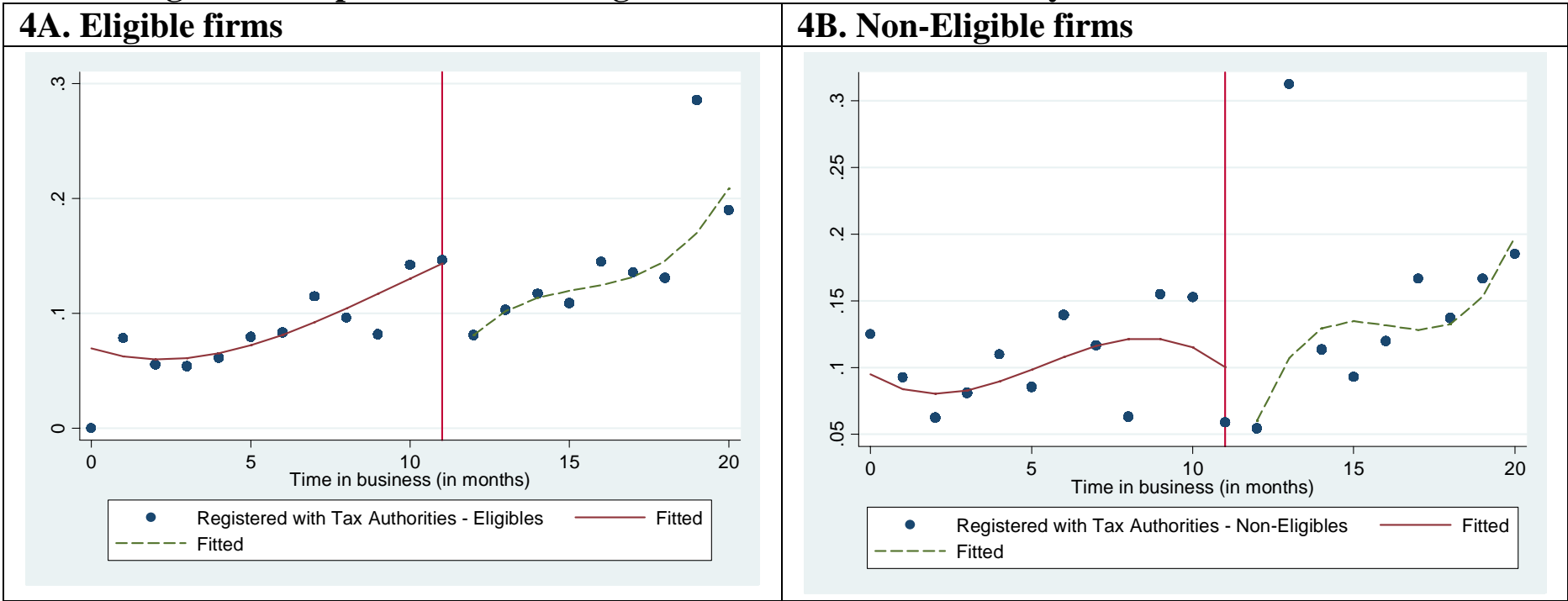

Notes: Authors' calculations using ECINF 1997 with firms born between February 1996 to October 1997. Entrepreneurs without college degree and 20-65 years old. 
Figure 5: Proportion of firms paying taxes

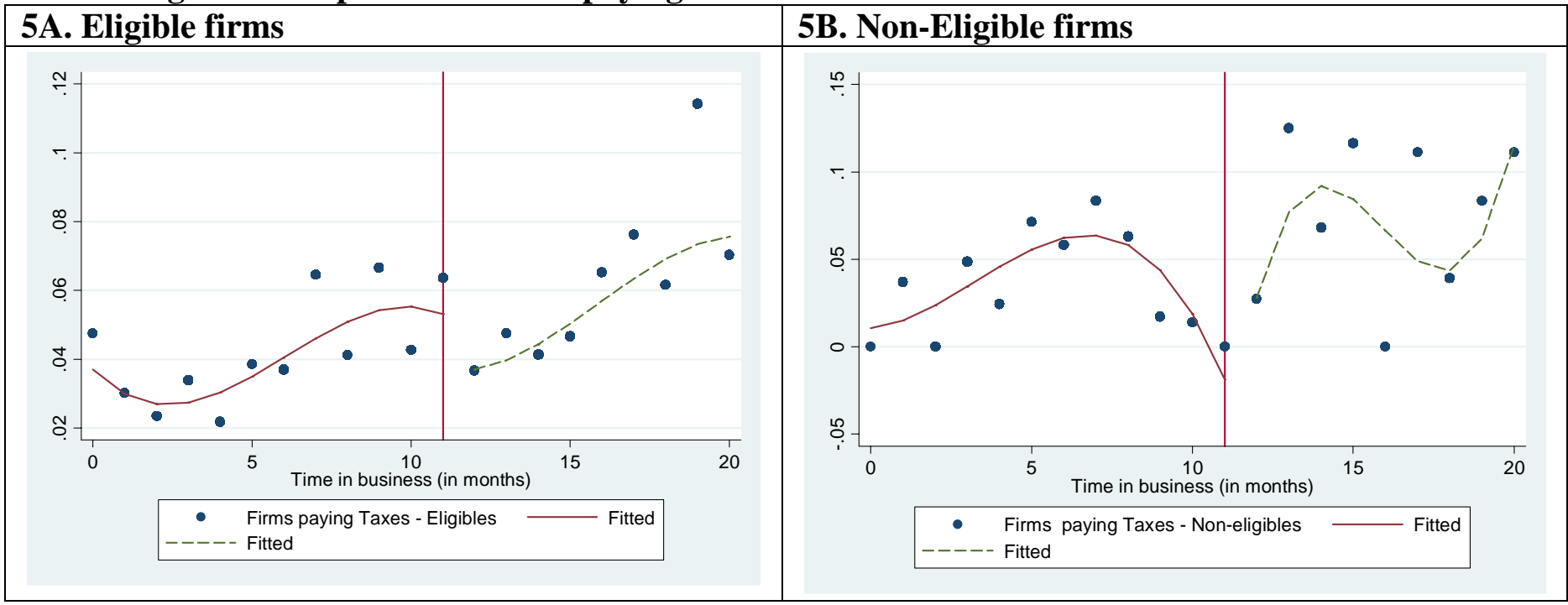

Notes: Authors' calculations using ECINF 1997 with firms born between February 1996 to October 1997. Entrepreneurs without college degree and 20-65 years old.

Figure 6: Proportion of firms paying social security

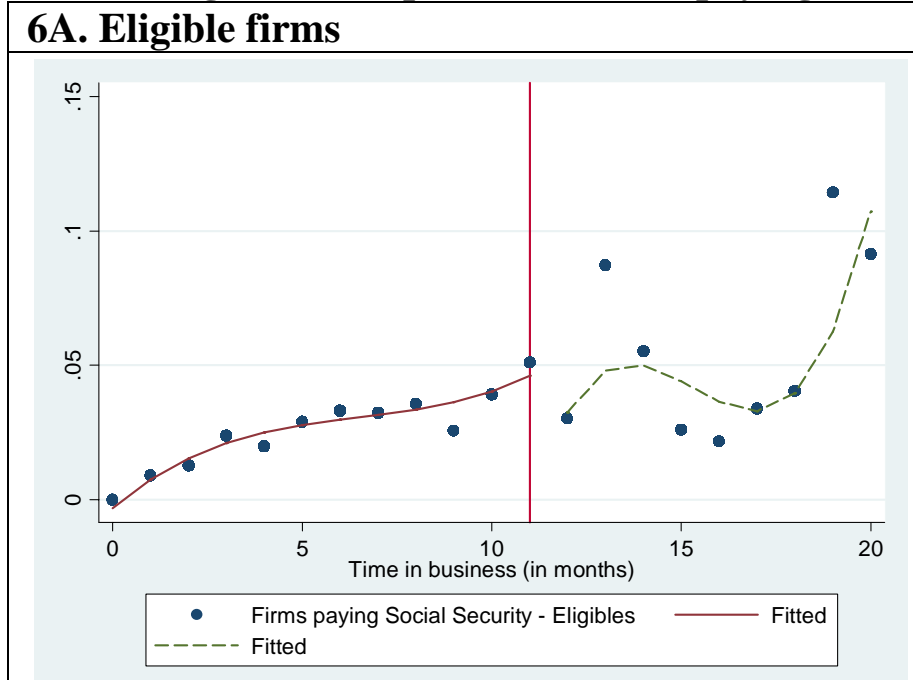

6B. Non-Eligible firms

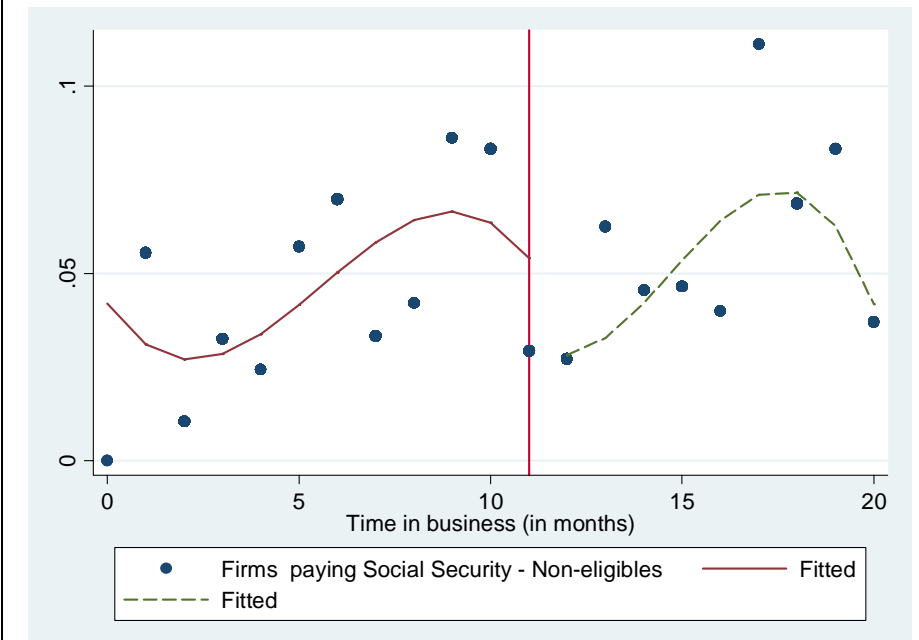

Notes: Authors' calculations using ECINF 1997 with firms born between February 1996 to October 1997. Entrepreneurs without college degree and 20-65 years old. 
Figure 7: First stage results with different bandwidths (Licensing)

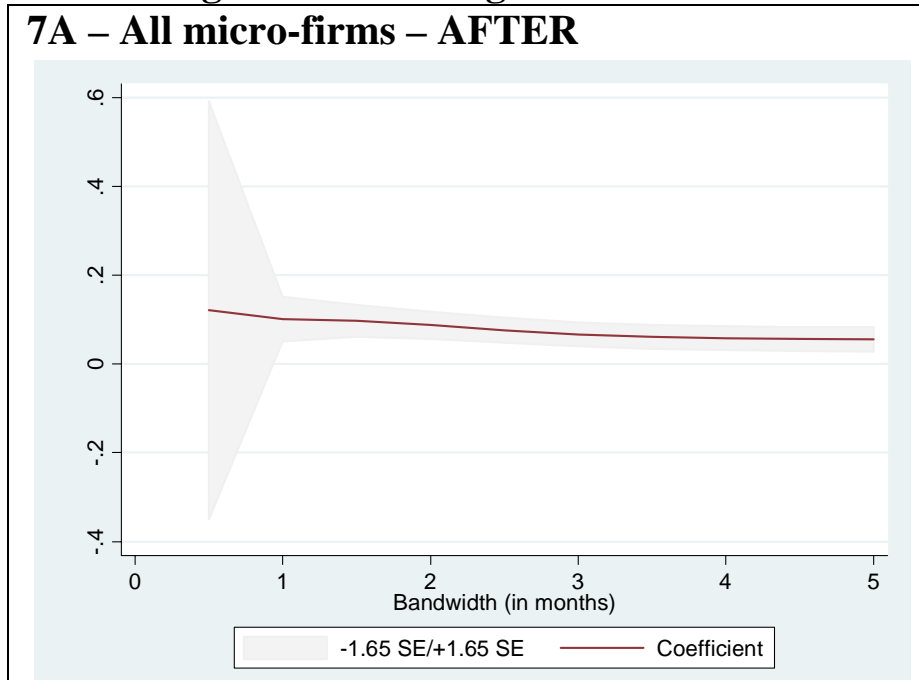

7B - All micro-firms - AFTER x ELIG

7C - Own-account workers - AFTER

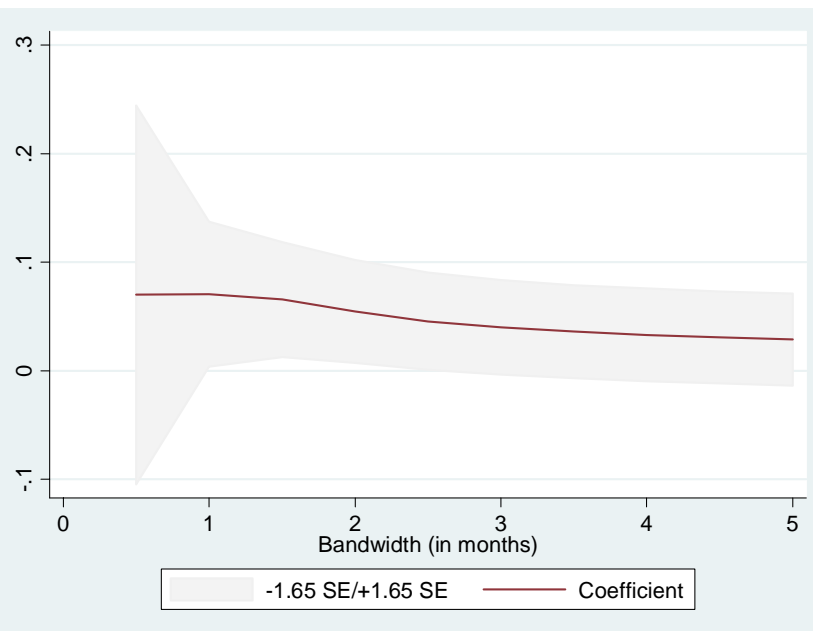

\section{D - Own-account workers - AFTER x ELIG}

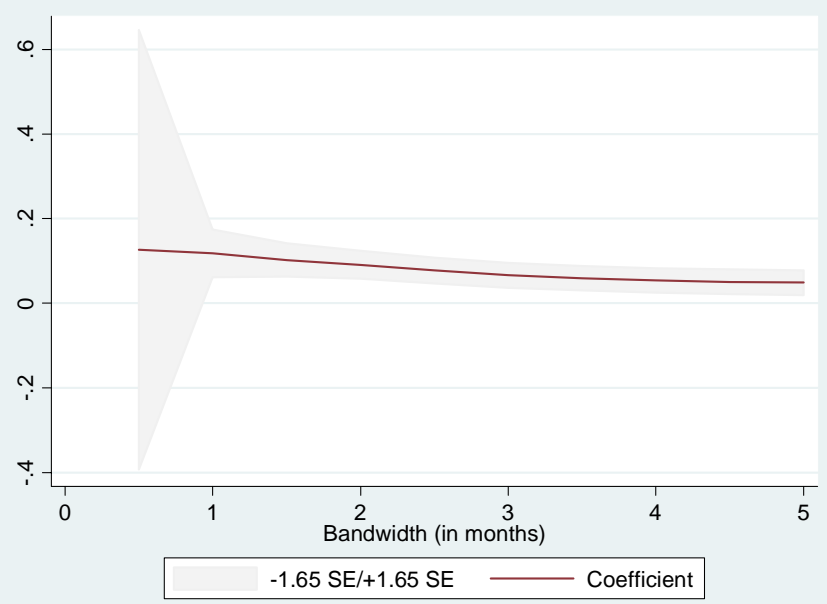

7E - Firms with at least one employee - AFTER

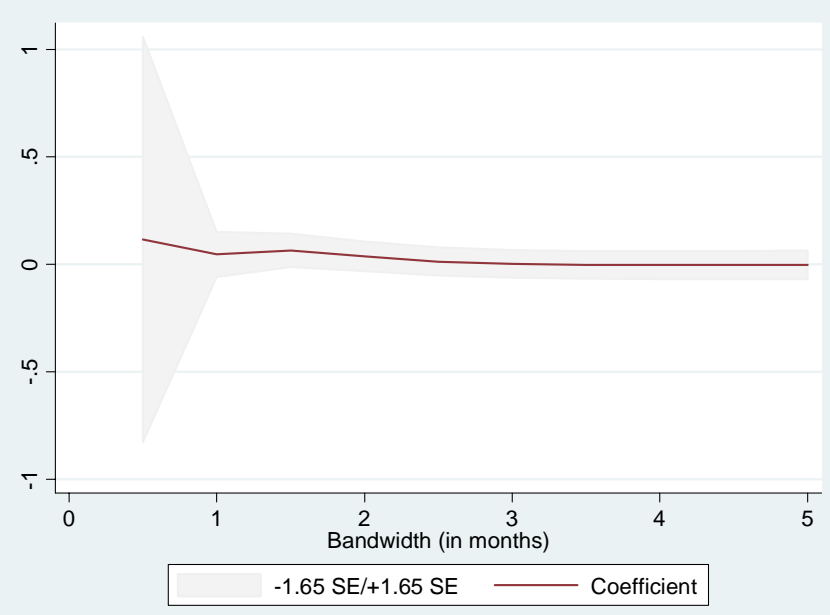

7F - Firms with at least one employee - AFTER $x$ ELIG

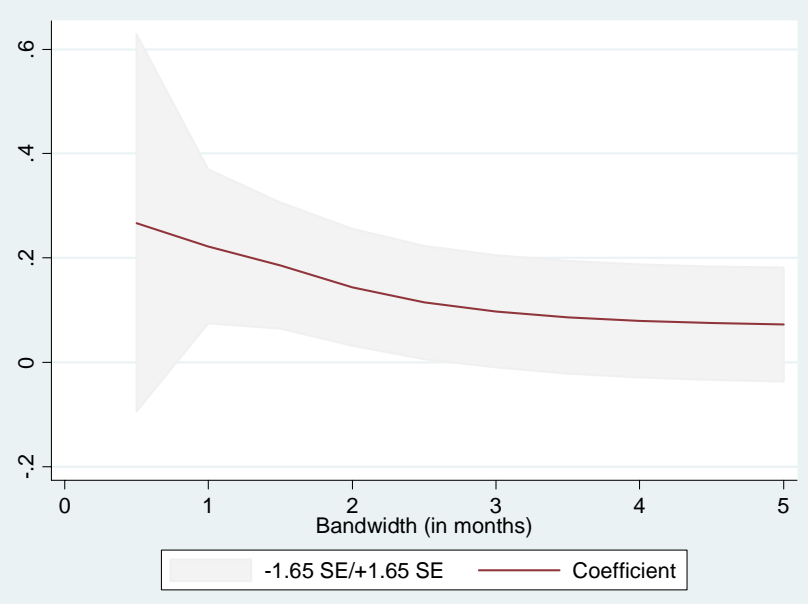


Figure 8: First stage results with different bandwidths (Registered as a legal entity)

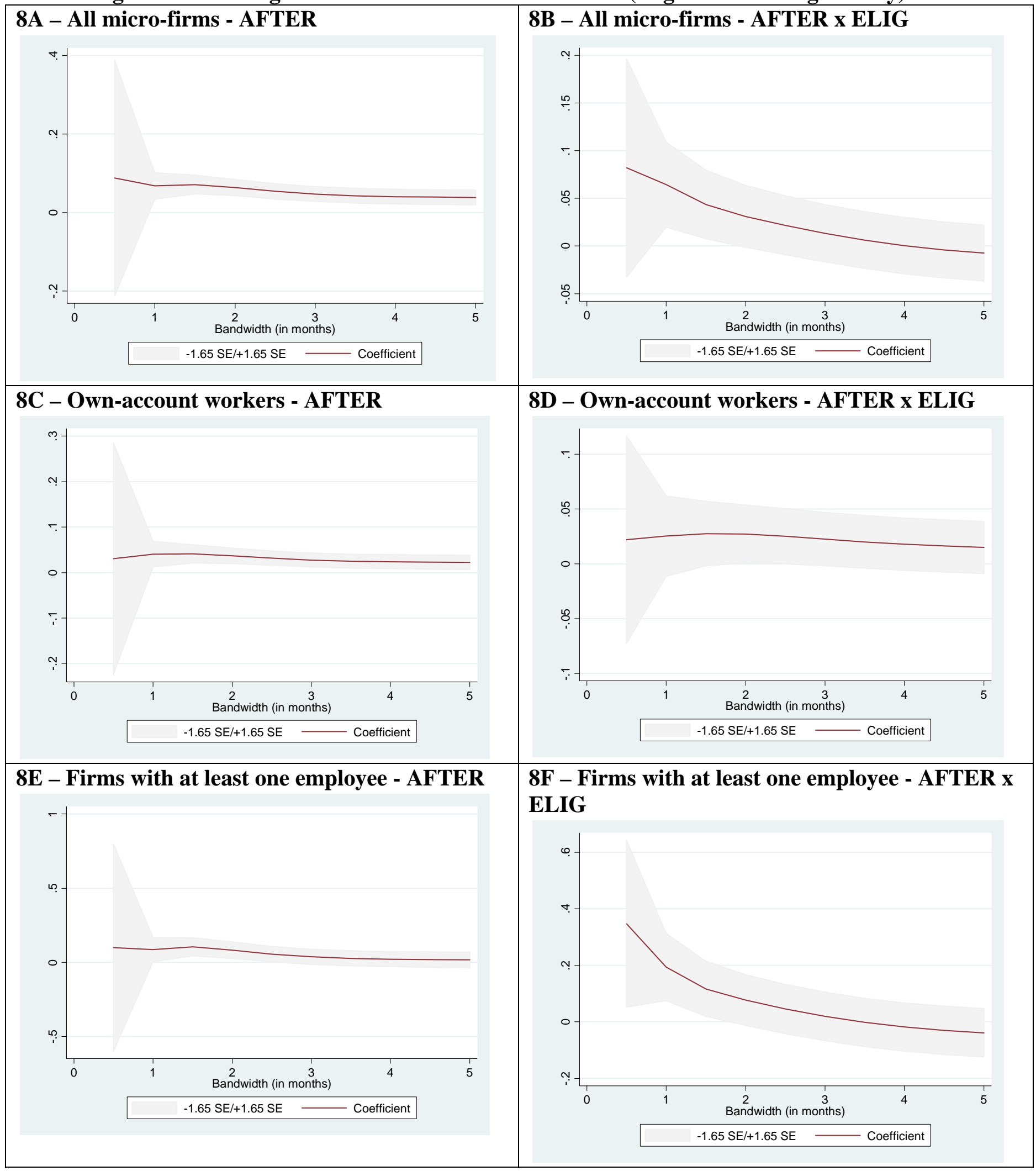

